\title{
PENGARUH PROMOSI PENJUALAN DAN CELEBRITY ENDORSER TERHADAP NIAT BELI FASHION BRAND LOKAL GIYOMI PADA GENERASI Y DAN Z
}

\author{
Dicky Adi Nugroho \\ Universitas Negeri Surabaya \\ dickyadine99@gmail.com \\ Sri Setyo Iriani \\ Universitas Negeri Surabaya \\ srisetyo@unesa.ac.id
}

\begin{abstract}
Marketing strategies change as technology develops. Marketers are demanded to be more creative in continuing to market their products so they will not be outdone by the times, fashion products are no exception. Giyomi is a local fashion brand that utilizes marketing with digital marketing using celebrity endorsers and offline marketing using sales promotions by holding bazaar tours and giving discounts for its products. however, this is still lacking interest among $Y$ and $Z$ generations because these generations prefer to use foreign brands such as ZARA and H\&M. This research design to determine the effect of sales promotion and celebrity endorser on purchasing intentions on local fashion brands $Y$ and $Z$ generations (Study on the Giyomi brand). The sampling technique of this research used judgmental sampling and snowball sampling. The target population is generation $Y$ and $Z$ with criteria that use Instagram social media, of course, with a personal account that has followed Giyomi's Instagram account and knows Giyomi's promotion and celebrity endorser contained on Instagram social media. The number of samples of this study was 110 people. The results of this study indicate there is a significant positive influence between sales promotion and celebrity endorsers on purchasing intentions on local fashion brands $Y$ and $Z$ generations.
\end{abstract}

Keywords: brand local; celebrity endorser; purchase intentions; sales promotions.

\section{PENDAHULUAN}

Asosiasi Penyelenggara Jasa Internet Indonesia (APJII) melakukan survei di tahun 2018 yang hasilnya menyatakan bahwa penetrasi pengguna internet berdasarkan karakter kota/ kabupaten yaitu sebesar 74,1\% (urban) dan 61,6\% (rural) (APJII, 2018). Selain itu, menurut hasil survei APJII 2018 rentang usia pengguna internet tertinggi merupakan kelompok yang masuk generasi Y (milenial) dan generasi Z (pasca milenial) (APJII, 2018; Bencsik, Juhász, \& Horváth-Csikós, 2016). Pembagian generasi dibagi menjadi 6 rentang usia menurut Bencsik, Juhász, \& Horváth-Csikós (2016) yaitu generasi yang lahir di tahun: 1925-1946 (generasi veteran), 1946-1960 (generasibaby boom), 19601980 (generasi X), 1980-1995 (generasi Y),1995-2010 (generasi Z), dan 2010+ (generasi alfa).

Dari hasil survei APJII (2018), internet tidak dapat lepas dari seseorang dalam melakukan kegiatankegiatan pribadinya tidak terkecuali kegiatan pemasaran. Sehingga muncul inovasi pemasaran berbasis internet yang biasa disebut digital marketing (Warmayana, 2018). Hal ini sesuai dengan pernyataan Kotler dan Amstrong (2006:237) yang menyatakan bahwa pemasaran secara online adalah bentuk pemasaran langsung yang tumbuh paling pesat. Pendapat lain juga dikemukakan oleh Morisson (2010:7) bahwa kegiatan komunikasi pemasaran mencakup enam hal yaitu: memasang iklan (advertising); pemasaran langsung (direct marketing); promosi penjulan (sales promotion); penjualan personal (personal selling); penjualan internet/interaktif (interactive/internet marketing); dan hubungan masyarakat (public relations) untuk mencapai komunikasi pemasaran yang lebih efektif.

Salah satu online shop yang juga memanfaatkan komunikasi pemasaran untuk menarik perhatian calon konsumen yaitu Giyomi. Giyomi merupakan salah satu home clothing baik untuk laki-laki maupun perempuan, yang telah berdiri sejak tahun 2013 dengan pemilik Nadia Prasetyo yang semula adalah online shop yang bersifat reseller. Sampai saat ini, Giyomi memanfaatkan promosi penjualan dan celebrity endorsement sebagai strategi pemasaran. Giyomi menggunakan bentuk promosi penjualan yang aktif yaitu: Online sale khusus pada marketplace Shopee dan diskon yang dirangkai 
bersama event bazar diberbagai kota serta program diskon lain. Diskon tersebut diadakan Giyomi melalui media instagram secara berperiode. Bazar merupakan program unggulan yang sering dilakukan Giyomi, di mana menawarkan berbagai barang di kota yang akan Giyomi datangi, di kota tersebut Giyomi akan membuka booth dalam kurun waktu tertentu. Program diskon lainnya yaitu diskon pada bulan tertentu seperti Ramadhan sale dan paket bundling untuk beberapa item saja yang tentunya untuk menambah niat beli konsumen baru bagi Giyomi (Khansa, 2018).

Metode-metode promosi yang dilakukan Giyomi sesuai dengan penelitian yang dilakukan oleh Chi, Yeh,dan Huang (2011) yang menyatakan bahwa promosi penjualan berpengauh signifikan terhadap niat beli. Didukung dengan penelitian yang dilakukan oleh Ya dan Chang (2017) bahwa promosi penjualan berpengaruh positif terhadap niat beli. Selain memberikan promosi penjualan, Giyomi juga mengandalkan Dwi Handayani Syah Putri atau dikenal dengan akun instagram @ dwihandaanda, yang merupakan juru bicara brand Wardah dan juga merupakan runner-up ajang World Muslimah 2012 menjadi celebrity endorsement yang mampu menarik perhatian masyarakat yang akan berdampak pada niat beli, tentunya menguntungkan. bagi keberlangsungan brand Giyomi (instagram.com/giyomi.id, 2019)

Menurut Schiffman dan Kanuk (2007:300), celebrity endorser merupakan selebritis yang dipilih perusahaan untuk mempromosikan produk dan jasanya guna memberikan pernyataan dan dukungan, sebagai aktor dalam iklan, sekaligus menjadi juru bicara. Pernyataan tersebut didukung dengan penelitian yang dilakukan oleh Yeo et al (2015) bahwa celebrity endorser dengan menggunakan indikator keahlian,kepercayaan,dan daya tarik menunjukkan hubungan yang signifikan terhadap niat beli. Penelitian lain yang dilakukan oleh Haryantanah dan Ekawati (2015) juga menujukkan bahwa celebrity endorser berpengaruh positif dan signifikan terhadap niat beli.

Namun dari penjelasan tersebut minat beli fashion brand lokal pada generasi Y dan Z di Surabaya, menurun karena adanya brand luar negeri seperti ZARA dan HNM. Generasi Y dan Z pada saat ini lebih mementingkan brand yang digunakan untuk kebutuhan fashionnya tanpa mempertimbangkan berbagai aspek yaitu kegunaan, kualitas, dan harga. Berikut contoh harga dari brand Zara, H\&M, dan Giyomi (cnbcindonesia.com, 2018).

\section{Tabel 1}

\section{DAFTAR HARGA BARANG PER BRAND}

\begin{tabular}{lll}
\hline \multicolumn{1}{c}{ Varian Produk } & Merek & \multicolumn{1}{c}{ Rentang Harga } \\
\hline Atasan/Kemeja & & Rp. $379.900-$ Rp. 999.900 \\
Jaket & ZARA & Rp. $699.900-$ Rp. 2.799 .000 \\
Tas & & Rp. $499.900-$ Rp. 1.899 .000 \\
Atasan/Kemeja & Rp. $149.900-$ Rp. 899.900 \\
Jaket & $H \& M$ & Rp. $499.900-$ Rp. 3.499 .000 \\
Tas & & Rp. $199.900-$ Rp. 1.899 .900 \\
Atasan/Kemeja & Rp. $125.000-$ Rp. 160.000 \\
Jaket & \multirow{2}{*}{ Giyomi } & Rp. $160.000-$ Rp. 210.000 \\
Tas & & Rp. $95.000-$ Rp. 170.000 \\
\hline
\end{tabular}

Dari tabel 1, diketahui bahwa harga produk fashion dengan brand lokal lebih murah dibandingkan dengan fashion brand luar. Selain itu, Giyomi juga telah menggunakan strategi promosi penjualan yang aktif dan dengan harga produk yang lebih murah dibandingkan ZARA dan H\&M, tidak lupa juga telah menggunakan influencer yang berpengalaman untuk lebih menarik perhatian. Akan tetapi hal tersebut kurang menarik perhatian generasi $\mathrm{Y}$ dan $\mathrm{Z}$ yang lebih senang dengan produk brand luar mengingat sebanyak $60 \%$ orang Indonesia lebih menyukai brand luar negeri dibanding brand lokal. (cnbcindonesia.com, 2018). Didukung penelitian Daud dan Fitrianto (2015) yang menyatakan bahwa celebrity endorser tidak berpengaruh terhadapa niat beli mengingat celebrity endorser yang digunakan Giyomi memiliki reputasi yang baik dan dapat dipercaya dikarenakan generasi $\mathrm{Y}$ dan $\mathrm{Z}$ 
Dicky Adi Nugroho \& Sri Setyo Iriani. Pengaruh Promosi Penjualan dan Celebrity Endorser terhadap Niat Beli Fashion Brand Lokal Giyomi pada Generasi Y dan Z

kurang meminati produk lokal.

Penelitian ini bertujuan untuk mengetahui pengaruh promosi penjualan dan pengaruh celebrity endorser terhadap niat beli fashion pada brand lokal Giyomi.

\section{KAJIAN PUSTAKA DAN PENGEMBANGAN HIPOTESIS}

\section{Promosi Penjualan}

Menurut Kotler dan Keller (2009), promosi penjualan merupakan alat insentif yang digunakan untuk merangsang pembelian agar terjadi lebih cepat atau lebih besar atas produk atau jasa tertentu. Pendapat lain yang menyatakan bahwa promosi penjualan merupakan aktivitas pemasaran yang berdampak memberi nilai tambah atau insentif baik kepada tenaga penjualan, distributor, maupun konsumen utama, serta dapat menstimulisasi penjualan dengan segera (Belch dan Belch, 2003:21).

Dimensi promosi penjualan menurut Kotler dan Keller (2009) adalah sampel, kupon, diskon, rabat, premi, program frekuensi, hadiah, kontes, undian, garansi produk dan promosi silang. Sedangkan menurut Syamsu dan Sanaji (2014), indikator promosi penjualan adalah potongan harga dan sampel gratis, pendapat lain oleh Prasetyo (2013) indikator yang digunakan adalah diskon, undian, bonus dan promosi event. Selanjutnya, Anwar dan Saino (2014) mengatakan indikator promosi penjualan adalah diskon, hadiah, barang promo, kontes, undian dan permainan. Sehingga dengan mengintegrasikan ketiga pendapat tersebut maka indikator promosi penjualan dalam penelitian ini menggunakan diskon dan promosi event.

\section{Celebrity Endorser}

Schiffman dan Kanuk (2007:249) menyatakan bahwa strategi pemasaran lain adalah menggunakan kelompok acuan yang mampu membangun niat konsumen untuk melakukan pembelian suatu produk. Hal tersebut disebut sebagai kelompok referensi atau kelompok acuan, di mana menurut Sumarwan (2017:305) kelompok acuan merupakan seorang individu atau kelompok orang yang memiliki kemampuan mempengaruhi perilaku seseorang yang merupakan referensi bagi seseorang dalam pengambilan keputusan. Kelompok acuan dapat berasal dari siapapun yang mampu membawa pengaruh termasuk celebrity endorser.

Celebrity Endorser merupakan bintang televisi, aktor film, atlet terkenal, bahkan sosok pribadi yang telah meninggal yang digunakan secara luas untuk mendukung merek (Shimp dan Andrews, 2013:290). Pendapat lain menyatakan bahwa celebrity endorser merupakan selebritis yang dipilih perusahaan untuk mempromosikan produk dan jasanya guna memberikan pernyataan dan dukungan, sebagai aktor dalam iklan, sekaligus menjadi juru bicara (Schifman dan Kanuk, 2007:300). Menurut Shimp dan Andrews (2013:292), dimensi dari celebrity endorser adalah kredibilitas, daya tarik dan kekuatan beroprasi melalui psikologis proses pemenuhan atau membangun kepatuhan. Penelitian yang dilakukan oleh Yeo et al (2015) menggunakan indikator celebity endorser yaitu keahlian, kepercayaan dan daya tarik. Sedangkan menurut Stephanie, Rumambi, dan Kunto (2013) indikator celebrity endorser adalah attractiveness, truthworthiness dan expertise.

Selanjutnya menurut Haryantana dan Ekawati (2015), indikator celebrity endorser yang digunakan adalah kemampuan intelektual, kesamaan kepribadian, keramahan, frekuensi penampilan di publik, kemampuan untuk menarik minat konsumen, dan kejujuran. Selain itu menurut McClelland (2016), indikator celebrity endorser yang digunakan adalah daya tarik, keahlian, kepercayaan kecocokan dan kesukaan. Sehigga dengan mengintegrasikan keempat pendapat tersebut maka indikator celebrity endorser yang digunakan pada penelitian ini adalah daya tarik, keahlian, kepercayaan dan kesukaan.

\section{Niat Beli}

Niat beli merupakan suatu kecenderungan pelanggan akan membeli suatu produk atau merek tertentu (Belch,2012:127). Menurut Kotler dan Keller (2009:186), niat beli adalah salah satu fase dari proses pengambilan keputusan yang muncul setelah dirasakannya suatu kebutuhan oleh seorang individu. Selain itu niat beli adalah suatu perilaku di mana konsumen memiliki rasa ingin membeli atau 
memilih suatu produk yang didasari oleh pengalaman dalam memilih, menggunakan, dan mengkonsumsi, serta mengikat suatu produk. Unsur dari niat beli tertuang pada model AIDA yaitu Attentions, Interest, Desire, dan Actions (Kotler dan Keller, 2009:189).

Ferdinand (2000:129) mengungkapkan bahwasanya niat beli dapat diidentifikasi melalui dimensi nilai transaksional, nilai frekuensi, nilai beli preferensi, dan nilai eksploratif. Sedangkan menurut McClelland (2016), indikator niat beli adalah mencari informasi tentang produk, mempertimbangkan untuk membeli produk dan berniat untuk membeli produk. Selanjutnya menurut Raharjo dan Sugiharto (2013), indikator niat beli adalah mencari informasi lebih tentang produk, mempertimbangkan untuk membeli produk, memiliki keinginan untuk mengetahui produk, tertarik untuk mencoba dan ingin membeli produk. Sehingga dengan mengintegrasikan indikator dari penelitian McClelland (2016) dengan Raharjo dan Sugiharto (2013), indikator niat beli pada penelitian ini adalah tertarik untuk mencari informasi, mempertimbangkan untuk membeli produk, tertarik untuk membeli produk, berniat untuk membeli produk.

\section{Hubungan antar Variabel}

Khansa (2018) menyatakan bahwa Giyomi menawarkan diskon up to $50 \%$ untuk konsumennya agar dapat meningkatkan jumlah pembelian. Promosi lain yang diberikan melalui bazar tour Giyomi dengan tujuan memperluas jaringan dan segmen pasar dari Giyomi. Berdasarkan penelitian yang dilakukan oleh Ya dan Chang (2017), promosi penjualan berpengaruh positif terhadap niat beli. Penelitian lain oleh Chi, Yeh, dan Huang (2011) menyatakan bahwa promosi penjualan berpengaruh signifikan terhadap niat beli. Syamsu dan Sanaji (2014) menyatakan bahwa promosi penjualan memiliki pengaruh positif, namun tidak signifikan terhadap niat beli. Yudhiartika dan Haryanto (2012) menyatakan bahwa promosi penjualan tidak berpengaruh secara signifikan terhadap niat beli. Penelitian lain menyatakan bahwa promosi penjualan berpengaruh terhadap niat beli (Prasetyo,2013).

\section{H1: Ada pengaruh promosi penjualan terhadap niat beli fashion brand lokal generasi Y dan Z.}

Schiffman dan Kanuk (2007:249) mengungkapkan bahwa kelompok acuan atau kelompok reverensi membentu perilaku dan nilai seseorang dalam melakukan tindakan. Sehingga niat beli konsumen dapat muncul jika terdapat pengaruh dari orang lain. Giyomi memanfaatkan kecantikan dan kemampuan Dwi Handayani Syah Putri atau dikenal dengan akun instagram @ dwihandaanda sebagai kelompok reverensi demi mempengaruhi seseorang untuk memunculkan niat beli pada brand lokal Giyomi ini, Dwi Handayani Syah Putri juga merupakan juru bicara brand Wardah dan juga merupakan runner up ajang World Muslimah 2012 dan dipercaya Giyomi menjadi celebrity endorsement yang mampu menarik perhatian masyarakat yang akan berdampak pada niat beli. (instagram.com/giyomi.id, 2019)

Selanjutnya penelitian yang dilakukan oleh Yeo et al (2015), celebrity endorser menunjukkan hubungan yang signifikan terhadap niat beli. Penelitian yang dilakukan oleh Rahardjo dan Sugiharto (2013) menunjukkan bahwa celebrity endorser berpengaruh terhadap niat beli. Penelitian lain oleh Haryantana dan Ekawati (2015) menunjukkan bahwa celebrity endorser berpengaruh positif dan signifikan terhadap niat beli. Hasil sebaliknya ditunjukkan oleh penelitian yang dilakukan oleh Stephanie, Rumambi, dan Kunto (2013) tidak dapat membuktikan pengaruh celebrity endorser terhadap niat beli. Penelitian lain oleh Daud dan Fitrianto (2015) juga menyatakan bahwa celebrity endorser tidak berpengaruh terhadap niat beli.

H2: Ada pengaruh celebrity endorser terhadap niat beli fashion brand lokal generasi Y dan Z.

\section{METODE PENELITIAN}

Jenis penelitian ini adalah penelitian riset konklusif yang bertujuan untuk menguji hipotesis dan hubungan spesifik. Data yang digunakan dalam penelitian ini adalah data primer menggunakan angket dan wawancara secara chatting dan data sekunder menggunakan penelitian terdahulu. Variabel bebas 
Dicky Adi Nugroho \& Sri Setyo Iriani. Pengaruh Promosi Penjualan dan Celebrity Endorser terhadap Niat Beli Fashion Brand Lokal Giyomi pada Generasi Y dan Z

yang terdapat pada penelitian ini adalah promosi penjualan dan celebrity endorser. Sedangkan variabel terikat dalam penelitian ini adalah niat beli. Populasi yang menjadi sasaran adalah generasi $Y$ dan $\mathrm{Z}$ dengan kriteria yang menggunakan media sosial Instagram, tentunya dengan akun pribadi yang sudah mengikuti akun Instagram Giyomi dan mengetahui promosi dan celebrity endorser Giyomi yang termuat pada sosial media instagram. Jumlah sampel penelitian ini adalah 110 orang. Teknik pengumpulan data yang digunakan adalah angket kuesioner yang didistribusikan secara online melalui Google Form yang disebar melalui media sosial Whatsapp group dan Instagram.

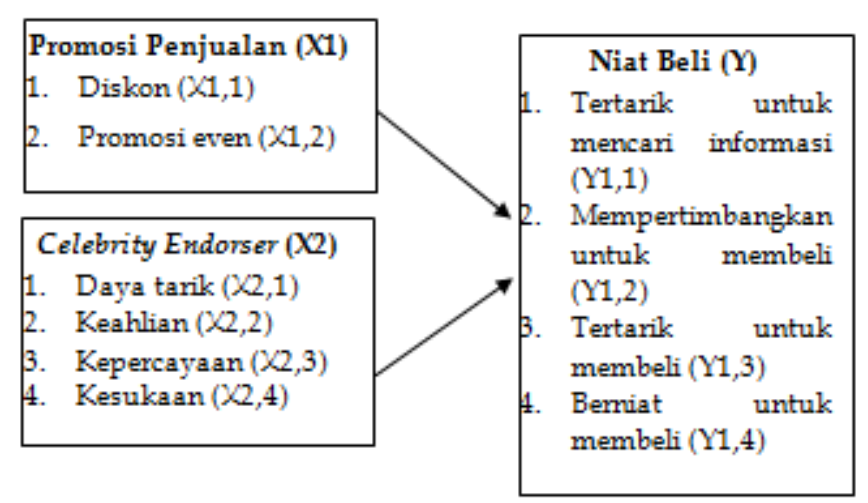

\section{Gambar 1 RANCANGAN PENELITIAN}

Teknik pengambilan sampel yang digunakan oleh peneliti adalah nonprobability sampling, di mana teknik yang digunakan adalah purposive sampling dan snowball sampling yang dipilih sesuai kriteria dari responden awal kemudian dilakukan uji validitas dan reliabilitas terhadap insturemen penelitian yang akan digunakan. Setelah lolos uji ini, maka selanjutnya akan disebar untuk memperoleh 110 responden uji asumsi klasik dan memenuhi model regresi linier berganda. Data yang terkumpul dianalisis dengan regresi linier berganda dengan menggunakan uji asumsi klasik yaitu uji normalitas, uji multikolinieritas dan uji heterokedastisitas. Selanjutnya, data akan diproses dengan uji hipotesis dengan menggunakan uji t.

\section{HASIL DAN PEMBAHASAN}

\section{Karakteristik Responden}

Deskripsi karakteristik responden pada penelitian ini berdasarkan demografi jenis kelamin dan usia pada pengikut akun instagram Giyomi. Tabel 2 menunjukkan karakteristik responden pada penelitian ini. Dari hasil tabel 2 menunjukkan bahwa responden terbanyak pada penelitian ini adalah perempuan dengan rentang usia terbanyak adalah 21-26 tahun. Hal tersebut disebabkan generasi usia tersebut merupakan kalangan yang sangat memperhatikan penampilan fashionnya untuk kegiatan sehari-hari seperti kuliah, bekerja, dan hangout.

\section{Hasil Uji Asumsi Klasik}

Hasil dari uji Normalitas dalam penelitian ini bertujuan untuk membuktikan nilai residual variabel terikat (niat beli) dan variabel bebas (promosi penjualan dan celebrity endorser) model regresi pada penelitian ini memiliki distribusi normal. Uji normalitas dalam penelitian ini dilakukan melalui Uji grafik normal P-plot dan Uji statistic non parametric Kolmogorov Smirnov. Hasil penjabaran uji grafik normal P-Plot menggambarkan poin-poin yang berbentuk titk-titik menyebar di sekitar garis diagonal dan mengikuti garis lurus diagonal yang menandakan bahwa data berdistribusi normal. Hasil uji statistic non parametric Kolmogorov Smirnov dengan output nilai Asymp. Sig. (2-tailed) sebesar 0,281 lebih besar dari 0,05 menunjukkan bahwa data berdistribusi normal.

Hasil uji multikolinieritas dengan metode VIF dalam penelitian ini dapat diketahui bahwa nilai tolerance dari kedua variabel bebas yaitu promosi penjualan dan celebrity endorser sebesar 0,806, di mana kedua nilai dari variabel tersebut bernilai lebih dari 0,1 yang menunjukkan tidak terjadi multikolinearitas. Selanjutnya, untuk nilai VIF dari kedua variabel bebas yaitu promosi penjualan dan 
celebrity endorser sebesar 1.241, di mana nilai tersebut kurang dari 10 yang menunjukkan bahwa tidak terjadi multikolinearitas.

Tabel 2.

KARAKTERISTIK RESPONDEN

\begin{tabular}{llcc}
\hline \multicolumn{2}{c}{ Karakteristik Responden } & Jumlah & Presentase (\%) \\
\hline \multirow{2}{*}{ Jenis Kelamin } & Laki-Laki & 16 & $14,5 \%$ \\
& Perempuan & 94 & $85,5 \%$ \\
\multirow{3}{*}{ Usia } & 15-20 Tahun & 6 & $5,5 \%$ \\
& 21-26 Tahun & 104 & $94,5 \%$ \\
& 27-35 Tahun & 0 & $0 \%$ \\
& Lainnya & 0 & $0 \%$ \\
\hline
\end{tabular}

Sumber: Data diolah

Hasil uji heteroskedastisitas menggunakan grafik scatterplot untuk mendeteksi hasil uji heteroskedastistas. Pada output Scatterplots di atas diketahui bahwa titik-titik data penyebar di atas dan di bawah atau di sekitar angka 0 , titik-titik tidak mengumpul hanya di atas atau di bawah saja dan penyebaran titik -titik data tidak berpola. Artinya, tidak terjadi masalah heteroskedastisitas. Gambar scatterplot dapat dilihat di Gambar 2.

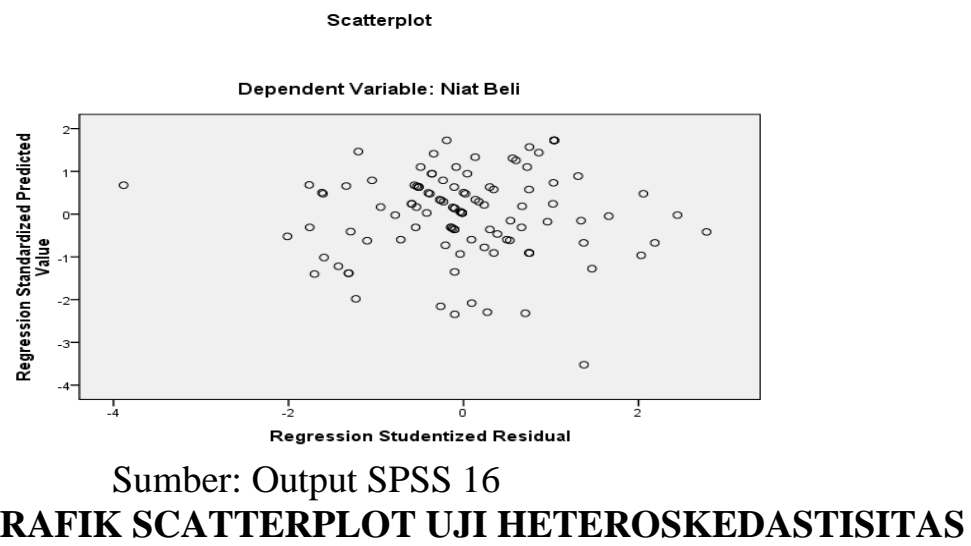

\section{Uji Regresi Linier Berganda}

Nilai konstanta $(\alpha)$ yang ada dalam penelitian ini adalah 7,156 dan positif $(+)$, maka dapat dijelaskan bahwa jika promosi penjualan dan celebrity endorser bernilai sama dengan nol (0), maka besarnya niat beli (Y) konsumen adalah 7,156 dan nilai positif menunjukkan bahwa niat beli tetap akan terjadi meskipun tanpa memperhatikan promosi penjualan dan celebrity endorser. Nilai koefisien variabel promosi penjualan adalah 0,315 dan positif $(+)$ artinya jika variabel promosi penjualan $\left(\mathrm{X}_{1}\right)$ ditingkatkan dan variabel lainnya tetap maka niat beli (Y) generasi Y dan Z pada brand Giyomi juga akan meningkat. Selanjutnya, nilai koefisien untuk variabel celebrity endorser adalah 0,265 dan bernilai positif artinya jika variabel celebrity endorser $\left(\mathrm{X}_{2}\right)$ ditingkatkan dan variabel lainnya tetap maka niat beli (Y) generasi Y dan $\mathrm{Z}$ pada brand Giyomi juga akan meningkat. Hasil statistik tersebut juga dapat disampaikan dalam persamaan (1).

$\mathrm{Y}=7,156+0,315 \mathrm{X}_{1}+0,265 \mathrm{X}_{2}$

\section{Uji Signifikansi Parsial (Uji t)}

Berdasarkan tabel 3, dapat dijelaskan bahwa nilai t hitung X1 sebesar 4.905 dan memiliki nilai signifikan sebesar 0,000 yang lebih kecil dari 0,05. Maka, $\mathrm{H}_{0}$ ditolak dan $\mathrm{H} 1$ diterima, sehingga variabel promosi penjualan (X1) berpengaruh terhadap niat beli (Y). Nilai t hitung X2 sebesar 4.043 
Dicky Adi Nugroho \& Sri Setyo Iriani. Pengaruh Promosi Penjualan dan Celebrity Endorser terhadap Niat Beli Fashion Brand Lokal Giyomi pada Generasi Y dan Z

dan disertai nilai signifikan senilai 0,000 yang memiliki nilai lebih kecil dari 0,05 . Artinya, $\mathrm{H}_{0}$ ditolak dan $\mathrm{H} 2$ diterima, sehingga variabel celebrity endorser (X2) berpengaruh terhadap niat beli (Y).

\section{Uji Kelayakan Model}

Dari hasil uji kelayakan model memperoleh nilai Adjusted $R$ Square penelitian ini sebesar $0.390=$ 39\%. Nilai tersebut menunjukkan bahwa promosi penjualan (X1) dan celebrity endorser (X2) terhadap variabel terikat niat beli fashion brand lokal generasi Y dan Z pada Giyomi sebesar 0.390 atau $39 \%$. Sedangkan sisanya $61 \%$, menunjukkan sebesar $61 \%$ penelitian ini dipengaruhi oleh variabel selain promosi penjualan dan celebrity endorser.

Tabel 3

\section{HASIL UJI REGRESI LINIER BERGANDA}

\begin{tabular}{|c|c|c|c|c|}
\hline Model & $\begin{array}{c}\text { Unstandardized Coefficient } \\
\text { B }\end{array}$ & $\mathbf{t}$ & sig & Keterangan \\
\hline Konstanta & 7.156 & 3.539 & .001 & \\
\hline Promosi Penjualan & .315 & 4.905 & .000 & Terima $\mathrm{H} 1$ \\
\hline Celebrity Endorser & .265 & 4.043 & .000 & Terima $\mathrm{H} 2$ \\
\hline
\end{tabular}

Sumber: Output SPSS, data diolah.

\section{Pengaruh Promosi Penjualan (X1) terhadap Niat Beli (Y)}

Nilai koefisien variabel promosi penjualan menunjukkan adanya pengaruh positif dan signifikan antara promosi penjualan (X1) dan niat beli (Y) fashion brand lokal generasi Y dan Z. Hasil ini membuktikan bahwa H1 dalam penelitian ini terbukti kebenarannya. Hasil penelitian ini mendukung penelitian Ya dan Chang (2017) dan Chi, Yeh, dan Huang (2011).

Dalam penelitian ini responden perempuan sebagai responden yang mendominasi dengan rentang usia terbanyak adalah 21-26 tahun. Selain itu, hasil tertinggi dari pernyataan item promosi penjualan terletak pada indikator diskon up to $50 \%$ dengan item pernyataan $\mathrm{X}_{1.1 .1}$ "Giyomi memberikan program diskon online sale up to 50\%". Hal ini dikarenakan usia tersebut merupakan generasi $\mathrm{Y}$ dan $\mathrm{Z}$ yang memperhatikan penampilan fashionnya untuk kepentingan hangout maupun kegiatan-kegiatan seharihari. Sehingga mereka sangat suka apabila menemukan produk fashion branded dan memiliki diskon tinggi. Karena generasi tersebut merasa bahwa produk yang memiliki brand sudah pasti memiliki kualitas yang baik.

Implikasi dari penelitian ini adalah strategi pemasaran yang digunakan oleh brand Giyomi menggunakan bazar tour dan diskon up to 50\% mampu menarik perhatian konsumen dan tepat sasaran. Produk fashion memang memerlukan promosi penjualan untuk menarik perhatian konsumen. Hal ini yang membuktikan bahwa promosi penjualan berpengaruh positif terhadap niat beli fashion brand lokal generasi Y dan Z. Selain itu, Giyomi disarankan untuk lebih inovatif dalam memberikan promosi penjualan seperti pemberian kupon atau gift/merchandise khusus bagi konsumen setia Giyomi sehingga promosi penjualan lebih menarik dan lebih membangun niat konsumen untuk melakukan pembelian pada brand Giyomi.

\section{Pengaruh Celebrity Endorser (X2) terhadap Niat Beli (Y)}

Nilai koefisien untuk variabel celebrity endorser adalah bernilai positif yang menunjukkan bahwa Celebrity Endorser $\left(\mathrm{X}_{2}\right)$ dan Niat Beli (Y) memiliki pengaruh yang positif. Hasil ini membuktikan bahwa H2 dalam penelitian ini. Hasil penelitian ini mendukung penelitian Yeo et al (2015), Rahardjo dan Sugiharto (2013) dan Haryantana dan Ekawati (2015).

Dalam penelitian ini, yang mendominasi adalah responden perempuan dengan usia 21-26 tahun. Selain itu hasil tertinggi dari pernyataan item celebrity endorser terletak pada daya tarik dengan item pernyataan $\mathrm{X}_{2.1 .2}$ "Celebrity Endorser Giyomi @dwihandaanda merupakan pribadi yang cantik" sebesar 4,47. Hal ini dikarenakan responden usia tersebut yang merupakan generasi $\mathrm{Y}$ dan $\mathrm{Z}$ sangat senang apabila melihat seseorang menggunakan fashion yang menarik dan baik terlebih lagi pemakai 
tersebut memiliki paras yang cantik. Sehingga hal tersebut akan menarik perhatian untuk mengikuti gaya fashion yang digunakan.

Implikasi dari penelitian ini adalah Giyomi memiliki celebrity endorser yang dengan kepribadian dan reputasi yang baik. Niat beli akan terbentuk dari konsumen jika influencer yang digunakan untuk memasarkan produk dipercayai oleh konsumen tersebut. Apabila celebrity endorser yang yang digunakan baik di mata konsumen maka akan meningkatkan niat konsumen untuk melakukan pembelian pada Giyomi. Hal ini yang mendasari celebrity endorser berpengaruh positif terhadap niat beli fashion brand lokal generasi Y dan Z. Selain itu celebrity endorser Giyomi disarankan untuk lebih interaktif dengan pengikut-pengikutnya di Instagram seperti menghadirkan giveaway bersama Giyomi atau memberikan hadiah untuk pengikut setianya sehingga hal tersebut akan lebih menunjang niat konsumen untuk membeli produk fashion Giyomi.

\section{KESIMPULAN}

Dari hasil penelitian maka diperoleh kesimpulan sebagai berikut: adanya pengaruh positif secara parsial variabel promosi penjualan terhadap niat beli fashion brand lokal generasi Y dan Z, adanya pengaruh positif secara parsial variabel celebrity endorser terhadap niat beli fashion brand lokal generasi $\mathrm{Y}$ dan $\mathrm{Z}$ dan variabel promosi penjualan lebih dominan dibandingkan variabel celebrity endorser dalam mempengaruhi niat beli fashion brand lokal generasi $\mathrm{Y}$ dan $\mathrm{Z}$.

Penelitian ini tentunya memiliki keterbatasan diantaranya: tidak menggunakan variabel moderasi sebagai penguat variabel independent sebelum menuju niat beli, cara pengumpulan data hanya menggunakan angket online, dan penelitian ini tidak menyediakan angket terbuka terkait kepercayaan dan kemudahan sehingga pembahasan yang diberikan kurang mendalam. Penelitian selanjutnya dapat menambahkan variabel moderasi seperti kepuasan atau kepercayaan untuk memperkuat promosi penjualan dan celebrity endorser terhadap niat beli fashion brand lokal generasi Y dan Z. Selain itu melakukan penambahan angket terbuka untuk memperoleh dan mengeksplor jawaban lebih detail lagi.

\section{DAFTAR PUSTAKA}

Aditya, Syamsu dan Sanaji. (2014) "Pengaruh pengetahuan produk dan promosi pejualan terhadap niat pembeli pelanggan telepon rumah pada layanan speedy pre wired" . Jurnal Ilmiah. Jurnal Ilmu Manajemen | Volume 2 Nomor 4 Oktober 2014

APJII. (2018). Infografis Penetrasi \& Perilaku Pengguna Internet Indonesia. (https://web.kominfo.go.id/sites/default/files/Laporan\%20Survei\%20APJII 2017_v1.3.pdf diakses pada 10 November 2019) Teknopreuner, 2018(31) August 2018), Hasil Survey.

Belch, G. B. (2012). Advertising an promotion: An Integrated Marketing Communication Perspective. New York: Mc Graw Hill.

Bencsik, A., Juhász, T., \& Horváth-Csikós, G. (2016). Y and Z Generations at Workplaces. Journal of Competitiveness, 6(3), 90-106. https://doi.org/10.7441/joc.2016.03.06

Chang, A. Y. P. (2017). A study on the effects of Sales Promotion on consumer involvement and purchase intention in Tourism industry. Eurasia Journal of Mathematics, Science and Technology Education, 13(12), 8323-8330. https://doi.org/10.12973/ejmste/77903

Chi, H, K., Yeh, H, R., Huang, M, W. (2008). The Influences of Advertising Endorser, Brand Image, Brand Equity, Price Promotion, on Purchase Intention. The Mediating Effect of Advertising Endorser. The Journal of Global Business Management, 5(1), pp.224-233. 
Dicky Adi Nugroho \& Sri Setyo Iriani. Pengaruh Promosi Penjualan dan Celebrity Endorser terhadap Niat Beli Fashion Brand Lokal Giyomi pada Generasi Y dan Z

Daud, I., \& Fitrianto, M. E. (2015). Peran Celebrity Endorser Dalam Membentuk. Manajemen Dan Bisnis Sriwijaya, 13(3).

Engel, J. F., G. Blackwell, dan P. W. Miniard. 1994. Perilaku Konsumen . Jilid 1. Binarupa Aksara, Jakarta.

Fern, Y. S., Boon, L. K., Ling, G. M., \& Huat, T. S. (2015). The effect of celebrity endorser towards customer purchase intention. Advanced Science Letters, 21(6), 2163-2165. https://doi.org/10.1166/asl.2015.6245

Ghozali, Imam. 2016. Aplikasi Analisis Multivariate dengan Program IBM SPSS 21 Update PLS Regresi. Semarang: Badan Penerbit Undip.

Giyomi.co.id. 2019. New Collection: Giyomi X Dwihandaanda (https://www.giyomi.co.id/shop/giyomixdwihandaanda . Diakses pada 3 Desember 2019)

Haryantana, I. P. G. H., \& Ekawati, N. W. (2015). Pengaruh Celebrity Endorser, Brand Image Dan Persepsi Kualitas Terhadap Niat Beli Sepeda Motor Honda Scoopy Di Kota Denpasar. Fakultas Ekonomi dan Bisnis Universitas Udayana ( Unud ), Bali , Indonesia PEN. E-Jurnal Manajemen UNUD, 4(9), 2806-2830.

HM.com. 2019. \#HmxME . (https://id.hm.com/hmxme.html. Diakses pada 3 Desember 2019)

Instagram.com. 2019. Giyomi Official (@giyomi.id). Foto dan Video Indtagram (www.instagram.com/giyomi.id, Diakses pada 14 Desember 2019)

Kansha, D. R. (2018). Efektivitas Penggunaan Endorsement oleh Online Shop Giyomi di Media Sosial Instagram. Online.

Kotler dan Keller, 2009, Manajemen Pemasaran, keputusan pembelian, Edisi 13 Jilid 1. Penerbit : Erlangga.

Kotler, Philip (2006). Manajemen pemasaran, jilid I, Edisi kesebelas, Jakarta, P.T Indeks Gramedia.

Lovelock, Wirtz. (2011). Services Marketing (People, Technology, Strategy). Pearson Education Limited. England

Malhotra, K. Naresh. 2009. Riset Pemasaran: Pendekatan Terapan (Jilid 1). Jakarta: PT INDEKS.

Morissan. (2010). Periklanan: Komunikasi Pemasaran Terpadu. Jakarta: Kencana Prenada Media Group.

Mughal, A., Mehmood, A., Mohi-ud-deen, A., \& Ahmad, B. (2014). The Impact of Promotional Tools on Consumer Buying Behavior: A Study from Pakistan. Journal of Public Administration and Governance, 4(3), 402. https://doi.org/10.5296/jpag.v4i3.6680

Prasetyo, E. (2013). Pengaruh Iklan, Promosi Penjualan Dan Penjualan Perorangan Terhadap Niat Beli Di CV. Lancar Makmur Motor Surakarta. Agora, 1(3), 2.

Schiffman, Leon.G. dan Leslie Lazar Kanuk. (2007). Perilaku Konsumen. Edisi Ke-7. Diterjemahkan oleh Zoelkifli Kasip. PT. Indeks, Jakarta.

Shimp, Terence A. And Andrews, J. Craig. (2013). Advertising, Promotion, and Other Aspects of Integrated Marketing Communications. 9th Edition. USA. Cengage Learning. 
Shimp, Terrence A, 2000. Advertising Promotion (Supplement Aspect of Integrated Marketing Communications). Fifht Edition. The Dryden Press Harcourt College Publisher.

Simamora, B. 2002. Panduan Riset Perilaku Konsumen. PT Gramedia Pustaka Utama. Jakarta

Stephanie, E., Rumambi, L. J., \& Sondang, Y. (2013). Analisa Pengaruh Rio Dewanto dan Donita Sebagai Celebrity Endorser Terhadap Minat Beli Rroduk Axe Anarchy Dengan Daya Tarik Iklan dan Efek Iklan Sebagai Variabel Intervening. Jurnal Manajemen Pemasaran, 1(2), 1-9.

Sugiyono. (2012). Metode Penelitian Kuantitatif Kualitatif dan R\&D. Bandung: Alfabeta.

Sumarwan, Ujang. 2015. Pemasaran Strategik:Prespektif Perilaku Konsumen, dan Marketing Plan. Jakarta: PT.Ghalia Indonesia.

Tjiptono, Fandy dan Gregorius Chandra. 2012. Pemasaran Strategik. Yogyakarta

Warmayana, I. G. A. K. (2018). Pemanfaatan Digital Marketing dalam Promosi Pariwisata pada Era Industri 4.0. Pariwisata Budaya: Jurnal Ilmiah Agama Dan Budaya, 3(2), 81. https://doi.org/10.25078/pba.v3i2.649

Yulistara, Arina. (2018). 60\% Orang Indonesia Pilih Beli Produk Asing Ketimbang Lokal. CNBC Indonesia. (https://www.cnbcindonesia.com/lifestyle/20180326194751-33-8635/60-orangindonesia-pilih-beli-produk-asing-ketimbang-lokal. Diakses 20 November 2019)

Zara.com. 2019. Beli di Zara.Com. (https://www.zara.com/id/id/help/beli-di-zara.com-h2.html. Diakses pada 3 Desember 2019) 